\title{
Interrelationship analysis of yield and fiber traits in promising genotypes of upland cotton
}

\author{
Munaiza Baloch ${ }^{1 *}$, Abdul Wahid Baloch ${ }^{1}$, Uzma Afreen Ansari ${ }^{1}$, Gul \\ Muhammad Baloch ${ }^{1}$, Saifullah Abro ${ }^{2}$, Naila Gandahi ${ }^{1}$, Ghulam Hussain \\ Baloch ${ }^{1}$, Abdul Majeed Baloch ${ }^{3}$, Muharam Ali ${ }^{4}$ and Irfan Ahmed \\ Baloch $^{1}$
}

1. Department of Plant Breeding \& Genetics, Sindh Agriculture University, Tandojam-Pakistan

2. Nuclear Institute of Agriculture, Tandojam-Pakistan

3. College of Horticulture, Northeast Agriculture University, Harbin, China

4. Department of Biotechnology, Sindh Agriculture University, Tandojam-Pakistan

*Corresponding author's email: balochbreeders@yahoo.com

Citation

Munaiza Baloch, Abdul Wahid Baloch, Uzma Afreen Ansari, Gul Muhammad Baloch, Saifullah Abro, Naila Gandahi, Ghulam Hussain Baloch, Abdul Majeed Baloch, Muharam Ali and Irfan Ahmed Baloch. Interrelationship analysis of yield and fiber traits in promising genotypes of upland cotton. Pure and Applied Biology. Vol. 5, Issue 2, 2016, pp263-269. http://dx.doi.org/10.19045/bspab.2016.50034

\begin{tabular}{llll}
\hline \hline Received: 22/01/2016 & Revised: 10/02/2016 & Accepted: 18/02/2016 & Online First: 04/03/2016 \\
\hline
\end{tabular}

\section{Abstract}

The present research was carried out at the experimental farm of Nuclear Institute of Agriculture, Tandojam during the year 2014, in order to work out the correlation and regression analysis in yield and fiber traits in promising genotypes of upland cotton. The research was carried out in randomized complete block design with three replications. The experimental materials composed of ten cotton varieties. Total nine traits were studied such as plant height $(\mathrm{cm})$, sympodial branches plant ${ }^{-1}$, bolls plant ${ }^{-1}$, boll weight $(\mathrm{g})$, seed cotton yield plant $^{-1}(\mathrm{~g})$, ginning outtern percentage (GOT\%), staple length $(\mathrm{mm})$ and seed index $(100$-seed weight, g). Analysis of variances revealed that significant differences $(\mathrm{P} \leq 0.05)$ existed among the varieties for all the studied traits, showing the availability of substantial genetic variability among the genotypes. Consequently, these promising cultivars can further be utilized in different breeding programs to improve yield and fiber quality traits in upland cotton. Correlation analysis showed that sympodial branches plant $^{-1}\left(\mathrm{r}=0.421^{*}\right)$, bolls plant ${ }^{-1}\left(\mathrm{r}=0.732^{* *}\right)$, boll weight $\left(\mathrm{r}=0.476^{*}\right)$ and staple length $\left(\mathrm{r}=0.812^{* *}\right)$ made significant and positive associations with seed cotton yield plant ${ }^{-1}$. Thus, selection for these traits will ultimately increase the chances to improve seed cotton yield plant ${ }^{-1}$. The coefficient of determination $\left(\mathrm{r}^{2}\right)$ further suggested that greater portion of total variability in seed cotton yield plant ${ }^{-1}$ was attributable to sympodial branches plant $^{-1}$, bolls plant ${ }^{-1}$, boll weight and staple length. Correlation and regression analysis suggested that sympodial branches plant ${ }^{-1}$, bolls plant ${ }^{-1}$, boll weight and staple length was the most important yield components traits which could be exploited as selection criteria for further improvement of cotton genotypes.

Key words: Upland cotton; Correlation analysis; Seed cotton yield; Fiber traits

Introduction

Cotton, Gossypium hirsutum L., belongs to family Malvaceae and is grown almost all over the world from time immemorial. In addition to the lint, cotton seed is used for oil extraction which makes about 80 percent 
of the national oil production. Cotton is mainly grown for fiber which is an economic component and plays a vital role for uplifting country's economy [1]. A huge population of the country is engaged in the fields of agriculture, ginning factories, textile mills, and business [2]. Cotton also plays a pivotal role in enhancing Pakistan's economy as being the major source of earning foreign exchange. Thus, it is considered as the back bone of the economy of Pakistan [3]. Yield is a complex trait which is influenced by genetic and climatic factors. Interaction among both these factors makes the selection procedure tough. For obtaining desirable cotton genotypes, information regarding interaction between yield and related components assist the breeders in the choice of desirable genotypes. The association analysis provides a good guide to envisage the corresponding change which occurs in one parameter at the expense of the proportionate change in the other [4]. Genetic variation and positive association of seed cotton yield with yield components was also observed in hirsutum cultivars [5]. Gui [6] found that the higher yield in cotton cultivars was mainly due to more number of bolls plant ${ }^{-1}$. For selection of yield and related parameters, understanding about correlation of yield and its relevant traits is a prerequisite.

\section{Materials and methods}

The field experiment was conducted at the experimental farm of Nuclear Institute of Agriculture, Tandojam, during kharif season 2014 , in order to find out the correlation and regression analysis between yield and yield contributing characters in commercially ten grown varieties such as Silver-Gold, HSP2, Silver-White, HSP-1, Kisanerly, CIM-598 (St-1), HSP-3, MNH-886 (St-2), HBC-SB814 and HBC-SB-134. The experimental design was laid out in a randomized complete block design with three replications. The plot size was kept 20'x15'. Row to row space was kept at $75 \mathrm{~cm}$ and plant to plant distance was $30 \mathrm{~cm}$. All the recommended agronomic practices and plant protection measures were applied to obtain healthy plants. A total of five plants of each cultivar from each replication selected at random were tagged in the field and laboratory. The traits examined were plant height $(\mathrm{cm})$, sympodial branches plant $^{-1}$, bolls plant ${ }^{-1}$, boll weight $(\mathrm{g})$, seed cotton yield plant ${ }^{-1}(\mathrm{~g})$, staple length $(\mathrm{mm})$, ginning outturn percentage (GOT\%) and seed index (100-seed weight, g). The collected data was subjected to the analysis of variance after Gomez and Gomez [7]. Correlation coefficients $(r)$, coefficients of determination $\left(\mathrm{r}^{2}\right)$, regression coefficients (b) and their significance determined after Snedecor and Cochran [8].

\section{Results and discussion}

The present study was carried out to appreciate the genetic systems which control the relationship of yield and its components. Investigations were, therefore, made on correlation and regression analysis using ten commercial cotton varieties. Based on the results, the performance of each cotton variety was measured by using simple correlation coefficient, coefficient of determination and regression coefficient analysis for the important quantitative and qualitative traits.

The analysis of variance (Table 1) showed that the genotypes differed significantly $(\mathrm{P} \leq 0.01)$ for all the studied characters, indicating the presence a vast genetic variability for these traits. Almost similar results have also been reported by several other workers, namely, Baloch [9] and Baloch [10]. These researchers also found the significant genetic variance for the number of traits, such as, plant height, sympodial branches plant ${ }^{-1}$, bolls plant $^{-1}$, boll weight and micronaire, while studying yield and its components. 
Table 1. Mean squares from analysis of variance for yield and fiber traits in upland cotton (Gossypium hirsutum L.)

\begin{tabular}{|l|c|c|c|}
\hline \multicolumn{1}{|c|}{ Source of variation } & $\begin{array}{c}\text { Replications } \\
\text { D.F. = 2 }\end{array}$ & $\begin{array}{c}\text { Genotypes } \\
\text { D.F. =9 }\end{array}$ & $\begin{array}{c}\text { Error } \\
\text { D.F. = 28 }\end{array}$ \\
\hline Plant height $^{\text {Sympodial branches plant }}{ }^{-1}$ & 10.288 & $115.215^{* *}$ & 9.940 \\
\hline Bolls plant $^{-1}$ & 11.541 & $51.958^{* *}$ & 12.372 \\
\hline Boll weight $_{\text {Seed cotton yield plant }}{ }^{-1}$ & 43.481 & $55.450^{* *}$ & 23.170 \\
\hline GOT\% & 0.004 & $0.967^{* *}$ & 0.01 \\
\hline Staple length & 0.06 & $1095.14^{* *}$ & 0.01 \\
\hline Seed index (100-seed weight, g) & 0.120 & $15.182^{* *}$ & 0.167 \\
\hline
\end{tabular}

Note: $* *=$ Significant at 0.01 level of probability

The results (Table 2) depicted that plant height had positive and significant relationship with bolls plant ${ }^{-1}\left(\mathrm{r}=0.433^{*}\right)$ and this association indicates that increase in plant height will cause correspondingly increase in bolls plant ${ }^{-1}$, which is a valuable indicator in cotton breeding. Similar results were also obtained by Salahuddin [11] and Rao and Gopinath [12] in their respective studies. However, plant height was nonsignificantly and negatively correlated with seed index $(\mathrm{r}=-0.038)$ and staple length $(\mathrm{r}=-$ 0.032 ), indicating that a great care should be taken while selecting taller plants of cotton since plant height tends to have negative impact on seed index and staple length. Nonetheless, the medium-tall plants with production capacity of setting maximum number of bolls which is the ultimate result for obtaining higher yields are more desirable. The coefficient of determination $\left(\mathrm{r}^{2}\right)$ revealed that $11.56 \%$ of total variability in seed cotton yield plant $^{-1}$ was due to its association with plant height. The regression coefficient (b) indicated that a unit increases in plant height will cause an increase of 1.02 gms in seed cotton yield plant ${ }^{-1}$.

Sympodial branches plant ${ }^{-1}$ is one of the major quantitative traits and is considered as fruiting branches which bears bolls in cotton plant, hence contributes directly towards seed cotton yield. For that reason, plant breeders and researchers are interested to maximize sympodial branches plant ${ }^{-1}$ which does serve as good criterion for selecting high yielding cotton varieties. In the present research work, it is evident that sympodial branches plant $^{-1}$ were significantly and positively $\left(\mathrm{r}=0.415^{*}\right)$ correlated with seed cotton yield plant ${ }^{-1}$ (Table 2 ). It shows that a unit increases in sympodial branches plant ${ }^{-1}$, resulted into a proportional increase in seed cotton yield plant ${ }^{-1}$. Sympodial branches plant $^{-1}$ also showed positive but nonsignificant associations with various traits such as bolls plant ${ }^{-1}$, boll weight, GOT\% and seed index, indicating that increase in sympodial branches will also cause a negligible increase in these traits. The results reported by Abbas [13] and Farooq [14] were in accordance with our findings. The coefficient of determination $\left(\mathrm{r}^{2}\right)$ revealed $14.00 \%$ variation in the seed cotton yield plant $^{-1}$, due to its relationship with sympodial branches plant $^{-1}$. Regression coefficient (b) exhibited that a unit increases in sympodial branches plant ${ }^{-1}$, resulted into a proportional increase of $1.657 \mathrm{gms}$ in seed cotton yield plant ${ }^{-1}$.

Bolls plant ${ }^{-1}$ is the major yield contributing factor having strong correlation with seed cotton yield. Considering the improvement of this vital trait, it has generally been observed that an increase in boll number in cotton plant 
will ultimately increase the seed cotton yield. The results (Table 2) indicates positive association of bolls plant ${ }^{-1}$ with seed cotton yield plant $^{-1} \quad(\mathrm{r}=0.732 * *)$, yet showed negative and non-significant correlation with boll weight, GOT\% and seed index. These associations indicated that increase in number of bolls plant ${ }^{-1}$ will cause markedly increase in seed cotton yield, while its increase will simultaneously cause a little negative impact on boll weight, GOT\% and seed index. It seems that cotton production could be improved by the increase in number of bolls plant ${ }^{-1}$. These results are in accordance with the findings of Islam [15] and Vinodhana [16]. The coefficient of determination $\left(\mathrm{r}^{2}\right)$ revealed $53.50 \%$ of the total variation in seed cotton yield plant $^{-1}$ attributable to the variation in bolls plant ${ }^{-1}$. The regression coefficient (b) indicated that for a unit increases in bolls plant ${ }^{-1}$, there would be a relative increase of $32.696 \mathrm{gms}$ in seed cotton yield plant ${ }^{-1}$.

Boll weight has direct effect on seed cotton yield since the boll weight increases, the yield may also increase. The correlation results (Table 2) indicated that boll weight made positive and significant association with seed cotton yield plant ${ }^{-1}\left(r=0.476^{*}\right)$. This correlation indicates that an increase in boll weight will considerably increase seed cotton yield plant ${ }^{-1}$. Yet, non-significant and positive correlation of boll weight with GOT\% and staple length was also observed, which signifies that a small increase may be obtained in these both traits, while genotypes are being selected for boll weight. The positive relationship between boll weight and seed cotton yield have been reported by [13] and Pujer [17]. The coefficient of determination $\left(\mathrm{r}^{2}\right)$ determined that boll weight was responsible for $20.40 \%$ variation in seed cotton yield plant $^{-1}$. The regression coefficient (b) suggested that a unit increases in boll weight, there would be a corresponding increase of 3.748 gms in seed cotton yield plant ${ }^{-1}$.

GOT\% is a complex polygenic trait which is mostly affected by the dynamic changes of environment. Principally, it depends on lint weight that has the direct effect on GOT\%. Production plant ${ }^{-1}$ and per unit area can be improved by selecting the genotypes having high ginning outturn. The results (Table 2), showing that GOT\% made significant and negative association $(-0.430 *)$ with staple length, while it was negatively and nonsignificantly associated with seed cotton yield plant $^{-1}$. These results indicated that increasing GOT\% will correspondingly decrease staple length. Our results are in agreement with those of Salahuddin [11], who also recorded negative association with GOT\%. The coefficient of determination $\left(\mathrm{r}^{2}\right)$ determined that GOT\% was responsible for $11.20 \%$ variation in seed cotton yield plant $^{-1}$. The regression coefficient suggested that a unit increases in GOT\% will result a decrease of $0.061 \mathrm{gms}$ in seed cotton yield plant $^{-1}$.

Among the fiber quality parameters, fiber length has been secured a distinct position since it is more useful for textile mills in yarn manufacturing. The results (Table 2) found in the present study indicated that there had been significant and positive $(\mathrm{r}=0.812 * *)$ relationship between staple length and seed cotton yield plant ${ }^{-1}$. Based on the obtained results, it could be inferred that significant progress could be achieved in improving staple length and seed cotton yield plant $^{-1}$ simultaneously. Farooq [3], during their studies related to correlation between staple length and seed cotton yield plant $^{-1}$, found the results which were in complete accordance to the results reported in this study. The coefficient of determination $\left(\mathrm{r}^{2}\right)$ indicated that 65.90 of total variability in seed cotton yield plant $^{-1}$ was due to its association with staple length; while regression coefficient (b) showed that 
a unit increases in staple length will result in an increase of $4.211 \mathrm{gms}$ in seed cotton yield plant $^{-1}$. Moreover, the correlation between seed index and seed cotton yield plant $^{-1}$ was positive but non-significant $\left(\mathrm{r}=0.046^{\mathrm{NS}}\right)$, it implies that association between these two important traits is silent. The coefficient of determination $\left(\mathrm{r}^{2}\right)$ explained that $0.02 \%$ of total variability in seed cotton yield plant $^{-1}$ was due to its association with seed index; while regression coefficient (b) described that a unit increases in seed index will result in an increase of $0.781 \mathrm{gms}$ in seed cotton yield plant $^{-1}$.

Table 2. Correlation and regression analysis of various traits in upland cotton genotypes

\begin{tabular}{|c|c|c|c|}
\hline Character associations & $\begin{array}{l}\text { Correlation } \\
\text { Coefficient(r) }\end{array}$ & $\begin{array}{c}\text { Coefficient of } \\
\text { determination }\left(\mathbf{r}^{2}\right)\end{array}$ & $\begin{array}{c}\text { Regression } \\
\text { coefficient (b) }\end{array}$ \\
\hline Plant height vs Monopodial branches plant ${ }^{-1}$ & $-0.061^{\mathrm{NS}}$ & 0.003 & -0.008 \\
\hline Plant height vs Sympodial branches plant ${ }^{-1}$ & $0.051^{\mathrm{NS}}$ & 0.002 & 0.034 \\
\hline Plant height vs Bolls plant ${ }^{-1}$ & $0.433^{*}$ & 0.187 & 0.029 \\
\hline Plant height vs Boll weight & $0.038^{\mathrm{NS}}$ & 0.001 & 0.002 \\
\hline Plant height vs Ginning outturn \% & $0.329^{\mathrm{NS}}$ & 0.108 & 0.119 \\
\hline Plant height vs Seed index & $-0.038^{\mathrm{NS}}$ & 0.001 & -0.003 \\
\hline Plant height vs Staple length & $-0.032^{\mathrm{NS}}$ & 0.001 & -0.018 \\
\hline Plant height vs Seed cotton yield plant ${ }^{-1}$ & $0.34^{\mathrm{NS}}$ & 0.115 & 1.022 \\
\hline Sympodial branches plant ${ }^{-1}$ vs Bolls plant ${ }^{-1}$ & $0.227^{\mathrm{NS}}$ & 0.051 & 0.023 \\
\hline Sympodial branches plant ${ }^{-1}$ vs Boll weight & $0.228^{\mathrm{NS}}$ & 0.051 & 0.003 \\
\hline Sympodial branches plant ${ }^{-1}$ vs Ginning outturn $\%$ & $0.046^{\mathrm{NS}}$ & 0.002 & 0.092 \\
\hline Sympodial branches plant ${ }^{-1}$ vs Seed index & $-0.17^{\mathrm{NS}}$ & 0.028 & -0.055 \\
\hline Sympodial branches plant ${ }^{-1}$ vs Staple length & $0.421^{*}$ & 0.177 & 0.359 \\
\hline $\begin{array}{l}\text { Sympodial branches plant }{ }^{-1} \text { vs Seed cotton yield } \\
\text { plant }^{-1}\end{array}$ & $0.415^{*}$ & 0.140 & 1.657 \\
\hline Bolls plant ${ }^{-1}$ vs Boll weight & $-0.242^{\mathrm{NS}}$ & 0.058 & -0.175 \\
\hline Bolls plant $^{-1}$ vs Ginning outturn $\%$ & $-0.159^{\mathrm{NS}}$ & 0.025 & -0.867 \\
\hline Bolls plant ${ }^{-1}$ vs Seed index & $-0.22^{\mathrm{NS}}$ & 0.048 & -0.268 \\
\hline Bolls plant ${ }^{-1}$ vs Staple length & $0.266^{\mathrm{NS}}$ & 0.070 & 2.286 \\
\hline Bolls plant ${ }^{-1}$ vs Seed cotton yield plant $^{-1}$ & $0.732^{* *}$ & 0.535 & 32.696 \\
\hline Boll weight vs Ginning outturn $\%$ & $0.027^{\mathrm{NS}}$ & 0.0007 & 0.206 \\
\hline Boll weight vs Seed index & $-0.173^{\mathrm{NS}}$ & 0.029 & -0.291 \\
\hline Boll weight vs Staple length & $0.312^{\mathrm{NS}}$ & 0.097 & 3.707 \\
\hline Boll weight vs Seed cotton yield plant ${ }^{-1}$ & $0.476^{*}$ & 0.201 & 3.748 \\
\hline Ginning outturn vs Seed index & $-0.271^{\mathrm{NS}}$ & 0.073 & -2.741 \\
\hline Ginning outturn vs Staple length & $-0.430^{*}$ & 0.184 & -0.678 \\
\hline Ginning outturn vs Seed cotton yield plant ${ }^{-1}$ & $-0.335^{\mathrm{NS}}$ & 0.112 & -0.061 \\
\hline Seed index vs Staple length & $-0.111^{\mathrm{NS}}$ & 0.012 & -1.664 \\
\hline Seed index vs Seed cotton yield plant ${ }^{-1}$ & $0.046^{\mathrm{NS}}$ & 0.002 & 0.781 \\
\hline Staple length vs Seed cotton yield plant ${ }^{-1}$ & $0.812^{* *}$ & -0.659 & 4.211 \\
\hline
\end{tabular}

$* *=$ Significant at $0.01 p$ value; $*=$ Significant at $0.05 p$ value; $\mathrm{NS}=$ Non-Significant

\section{Authors' contributions}

Conceived and designed the experiments: $\mathrm{M}$ Baloch, GM Baloch \& S Abro. Performed the experiments: UA Ansari, N Gandahi \& IA Baloch. Analyzed the data: S Abro \&
AM Baloch. Contributed reagents/ materials/ analyses tools: GH Baloch. Wrote the paper: AW Bloch, M Baloch \& M Ali. References 
1. Riaz M, Farooq J, Sakhawat G, Mahmood A, Sadiq MA \& Yaseen M (2013). Genotypic variability for root/shoot parameters under water stress in some advanced lines of cotton (Gossypium hirsutum L.). Genetics Mol Res 12 (1): 552-561.

2. Imran M, Shakeel A, Farooq J, Saeed A, Farooq A \& Riaz M (2011). Genetic studies of fiber quality parameter and earliness related traits in upland cotton (Gossypium hirsutum L.). Advances Agri Bot 3(3):151-159.

3. Farooq J, Anwar M, Riaz M, Farooq A, Mahmood A, Shahid MTH, Shahid MR \& Ilahi F (2014). Correlation and path coefficient analysis of earliness, fiber quality and yield contributing traits in cotton (Gossypium hirsutum L.). The $J$ Animal \& Plant Sci 24(3): 781-786.

4. Ahmad W, Khan NU, Khalil MR, Parveen A, Ajmen U, Saeed M, Samiullah \& Shah SA (2008). Genetic variability and correlation analysis in upland cotton. Sarhad J Agri 24: 573580.

5. Méndez-Natera JR, Rondón A, Hernández J \& Merazo-Pinto JF (2012). Genetic studies in upland cotton. III. Genetic parameters, correlation and path analysis. Sabrao J Breed Genet 44(1): 112-128.

6. Gui DZ, Fan LK, Qun YZ, Wen XL, Fu XY, Nai YX, Qin L \& Kui Z (2003). Genetic improvement of cotton varieties in the Yangtse valley in China since 1950s. I. Improvement on yield and yield components. Acta Agro Sinica 29(2): 208-213.

7. Gomez KA \& Gomez AA (1984) Statistical Procedures for Agricultural Research. John Willey and Sons Inc., 2nd (ed.), New York, U.S.A. pp 680.

8. Snedecor WG \& Cochran WG (1980). Statistical method seventh ed. The
IOWA State Univ. Press Ames. Iowa, USA.

9. Baloch AW, Sahito JH, Ali M, Baloch GA, Baloch GA, Abro S, Channa SA, Baloch AM, Baloch GH \& Baloch GM (2014). Association analysis of yield and fiber traits in advance Pakistani upland cotton cultivars (Gossypium hirsutum L.) Adv Appl Agri Sci 2(12): 73-80.

10. Baloch M, Baloch AW, Baloch MK, Mallano IA, Baloch AM, Baloch NJ \& Abro S (2015). Association and heritability analysis for yield and fiber traits in promising genotypes of cotton (Gossypium hirsutum L.). Sindh Univ. Res Jour 47(2): 303-306.

11. Salahuddin S, Abro S, Kandhro MM, Salahuddin L \& Laghari S (2010). Correlation analysis of seed cotton yield with some quantitative traits in upland cotton (Gossypium hirsutum L.). Pak J Bot 42(6): 3799-3805.

12. Rao PJM \& Gopinath M (2013). Association analysis of yield and fibre quality characters in upland cotton (Gossypium hirsutum L.). Aust J Basic and App Sci 7(8): 787-790.

13. Abbas HH, Abid M \& Ali Q (2013). Genetic variability, heritability, genetic advance and correlation studies in cotton (Gossypium hirsutum L.). Int Res J Microb 4(6):156-161.

14. Farooq J, Anwar M, Riaz M, Mahmood A, Farooq A \& Iqbal MS (2013). Association and path analysis of earliness, yield and fiber related traits under cotton leaf curl virus $(\mathrm{CLCuV})$ intensive conditions in Gossypium hirsutum L. Pl Know J 2(1): 43-50.

15. Islam MK, Akhteruzzaman M \& Sharmin D. (2013). Multivariate and genetic component analysis of new cotton (gossypium hirsutum 1.) genotypes. Bangladesh J Prog Sci Tech 11(2): 185-190. 
16. Vinodhana NK, Gunasekaran M \& Vindhiyavarman P (2013). Genetic studies of variability, correlation and path analysis in cotton genotypes. Inter J Pure Appl Bioscie 1(5): 6-10.
17. Pujer S, Siwach SS, Deshmukh J, Sangwan RS \& Sangwan O (2014). Genetic variability, correlation and path analysis in upland cotton (Gossypium hirsutum L.). Elect J Pl Breed 5(2): 284-289. 